University of Wollongong

Research Online

$1-1-2014$

Governmental influences on the evolution of agricultural cooperatives in Vietnam: an institutional perspective with case studies

Anne Ngoc Vo

University of Wollongong, avo@uow.edu.au

V Le

Swinburne University of Technology

Follow this and additional works at: https://ro.uow.edu.au/buspapers

Part of the Business Commons

Research Online is the open access institutional repository for the University of Wollongong. For further information contact the UOW Library: research-pubs@uow.edu.au 


\title{
Governmental influences on the evolution of agricultural cooperatives in Vietnam: an institutional perspective with case studies
}

\begin{abstract}
Using an institutionalist approach as the main framework, this research examines the evolution of Vietnamese agricultural cooperatives over the last six decades through four distinct phases - the voluntary collectivization period of 1954-1975, the compulsory collectivization period of 1975-1981, the de-collectivization period of 1981-1997 and the neo-collectivization period since 1997. Based on two case studies, this research examines the role of the Vietnamese government in the development of Vietnamese agricultural cooperatives. It argues that a stable legal environment and appropriate government support are extremely important for the successful development of cooperatives. In terms of theoretical contribution, the study calls for an integration of the notion of institutional dynamics into the current 'static' institutionalism and emphasizes the need to analyse institutions' influences at central, local and organizational levels to understand the formation and development of organizations. It also offers some policy implications that are relevant to the development of cooperatives in other economies.
\end{abstract}

\section{Keywords}

agricultural, cooperatives, vietnam, institutional, perspective, governmental, case, influences, studies, evolution

\section{Disciplines \\ Business}

\section{Publication Details}

Cox, A. \& Le, V. (2014). Governmental influences on the evolution of agricultural cooperatives in Vietnam: an institutional perspective with case studies. Asia Pacific Business Review, 20 (3), 401-418. 


\title{
GOVERNMENTAL INFLUENCES ON THE EVOLUTION OF AGRICULTURAL COOPERATIVES IN VIETNAM
}

\begin{abstract}
Using an institutionalist approach as the main framework, this research examines the evolution of Vietnamese agricultural cooperatives over the last six decades through four distinct phases - the voluntary collectivization period of 1954-1975, the compulsory collectivization period of 1975-1981, the de-collectivization period of 1981 - 1997 and the neo-collectivization period since 1997. Based on two case studies, this research examines the role of the Vietnamese government in the development of Vietnamese agricultural cooperatives. It argues that a stable legal environment and appropriate government support are extremely important for the successful development of cooperatives. In terms of theoretical contribution, the study calls for an integration of the notion of institutional dynamics into the current 'static' institutionalism and emphasises the need to analyse institutions' influences at central, local and organisational levels to understand the formation and development of organisations. It also offers some policy implications that are relevant to the development of cooperatives in other economies.
\end{abstract}

Keywords: agricultural cooperatives; agricultural sector; collectivisation; de-collectivisation; economic reform; Vietnam, institutional theory. 


\section{Introduction}

Agriculture has long been an important sector in the Vietnamese economy.In 2011, earnings from the agriculture sector, which includes farming, forestry and fishery, accounted for 22.02 per cent of Vietnam's gross domestic product (GDP) (GSO 2012). The agriculture sector's share of economic output has declined in recent years, falling as a share of GDP from 40.49 per cent in 1991 to 25.77 per cent in 1997 and to around 20 per cent since 2005, as growth in other sectors of the economy has gained pace. However, Vietnam can be still called an agricultural country, as this sector remains the major source of employment (Wolz and Pham 2010). About 50 per cent of the Vietnamese labour force works in the agricultural sector (Nguyen 2012). In 2012, 68 per cent of the total population live in rural areas (GSO 2013, 63).

Agricultural cooperatives were an essential tool in combatting poverty in the 1950s and today play a crucial role in promoting effective allocation of resources and efficiency in production in Vietnam. However, ever since the birth of the co-operative movement in the agriculture sector, the development and evolution of this form of economic organisation has not been an easy process. The present day concept of agricultural cooperatives in Vietnam is the outcome of a long drawn out process of development. In retrospect, the development of Vietnamese agricultural cooperatives can be classified into four distinct phases: (1) the voluntary collectivisation period of 1954-1975; (2) the compulsory collectivisation period of 1975-1981; (3) the de-collectivisation period of 1981 - 1997; and (4) the neo-collectivisation period since 1997.

Despite the fact that agricultural collectivisation is a significant issue in contemporary Vietnamese political and economic history, there has been a limited amount of research on Vietnamese agricultural cooperatives. Existing research in this area has focused predominantly on the impact of agriculture sector on the Vietnamese economy (Truong 1987; Pingali and Vo 1992; Asian Development Bank 2002; Nguyen 2003), land reform and distribution (Moise 1983; Ravallion and Van de Walle 2003; Kerkvliet, 2006), agricultural techniques and innovation (Kaiser 1997; Foerster and Nguyen 1999; Nguyen 2000; Nguyen 2007), agricultural productivity (Bui 2003; Ho 2012), economic reforms and their impact on agriculture (Tran, 1998a), and government policies on agricultural development (Cohen 2001). Nevertheles, agricultural cooperatives have been understudied. In particular, there is a dearth of empirical studies on the evolution of agricultural 
cooperatives after Vietnam's new Cooperative Law of 1997 was launched and the role of the government and its agencies in this process. While there are a few notable studies, such as Truong (1987), Kerkvliet (1994, 1998, 2005, 2006), Tran (1998a, 1998b), Wolz and Pham (2010), which provided excellent analyses of agricultural cooperatives in different periods and of the impact of economic reforms on agricultural cooperatives, surprisingly there has not been a review of the performance of Vietnamese agricultural cooperatives that covers their development from their establishment in the 1950s until today.

The purpose of this study is, therefore, two-fold. Firstly, it aims to fill the gap in the literature by presenting a comprehensive review on Vietnam's agricultural cooperatives in the past six decades, with an emphasis on the period after the issue of the new 1997 Cooperatives Law. Secondly, it examines the development of contemporary agricultural cooperatives and the role that government agencies have played in this process. It explores some interrelated research questions, namely 1) How have Vietnamese agricultural cooperatives developed in the last six decades? 2) How do government agencies support the operations of agricultural cooperatives? and 3) How will the agricultural cooperatives evolve in the future?

\section{Literature Review}

This section highlights the relevance of the institutional framework for the analysis of economic structures and their behaviours. The institutionalist approach provides a valuable method for understanding the evolution and perpetuation of firms' behaviours. It then discusses the formation and evolution of Vietnamese agricultural cooperative models over the last six decades.

\section{The institutionalist approach and its application in understanding the evolution of firms}

Recent decades have witnessed the strong development of institutionalism. Comparative institutionalism analysis shows how different forms of economic organisation have been established, reproduced and changed in different market economies. It focuses on macrolevel societal institutions, in particular those that govern 'access to critical resources, especially labour and capital' (Whitley, 1999: 47). 
A systematic analysis of main national institutions and the interactions between these institutional arrangements and the activities of business organisations has been conceptualised in terms of 'societal logic' (Maurice et al., 1996), 'social systems of production’ (Hollingsworth and Boyer, 1997), ‘industrial orders’ (Herrigel, 1996), 'national industrial order’ (Lane, 1992) or ‘ national business systems’ (Whitley, 1999). Lane’s framework (1992) for example consists of the state, the financial system, the system of education and training, and to a lesser extent, the network of business associations and the system of industrial relations. Institutionalism explains how national institutions impose structural limitations on social actors and mediate or modify international pressures.

The effects of variations in businesses' institutional contexts on firms' behaviour are prominent, as a 'firm will gravitate towards the mode of coordination for which there is institutional support' (Hall and Soskice, 2001: 9). It is now widely accepted that the influence of such social institutions is so strong that they can almost be regarded as additional factors of production which become the basis of competitive advantage or disadvantage (Maurice at al., 1980; Lane, 1992; Porter, 1990). The role of the government for instance in economic planning and controlling in different countries affects a firm's organisational structure, its willingness to undertake long-term investments, and its dependence on state agencies in making decisions. In this case, what is 'rational' strategic behaviour is determined according to the role of the state.

The main contribution of the institutionalist approach is the establishment of a conceptual framework allowing study of firms' behaviours. However, the institutional perspective is criticised, firstly, as being insensitive to the 'soft' part in business organisations. Firm behaviour is over-determined by national stereotypes and the potential for human agency neglected within this framework (Gamble, 2001). Secondly, it might be problematic when applying an institutionalist approach to understand a business system in its transitional period, where 'previously latent institutions may suddenly become salient, old institutions may be put in the service of different ends or actors goals or strategies may shift within existing institutions' (Thelen and Steinmo 1992: 16).

\section{The Formation and Evolution of Vietnamese Agricultural Cooperative Models}

The International Cooperative Alliance defined a cooperative as 'an autonomous association of persons united voluntarily to meet their common economic, social, and 
cultural needs and aspirations through a jointly-owned and democratically-controlled enterprise' (ICA 2013). Neoclassical economists suggested that economic agents will coordinate their actions and engage in industry development activities whenever the benefits from doing so outweigh the costs. Chloupková (2002) argued that one of the characteristics of the cooperatives under the communist regime was forced membership, and as a result these cooperatives did not obey the principles set by ICA, even though they were touted by the government as collective farms aimed at 'joining resources and sharing benefits'. Parnell (1992) aptly pointed out that in communist countries, cooperatives were considered as a stepping stone to less centralised economies and in capitalist countries as a counterbalance to the strongly capitalist market-based system.

\section{Agricultural Cooperatives in the Voluntary Collectivisation Period of 1954-1975}

During the French colonial period, there was a high concentration of land in the hands of a small elite group of French and Vietnamese. According to Wolf $(1999,166)$, in the Northern region of Vietnam, 500 large landowners, both French and Vietnamese, owned 20 per cent of the land; another 17,000 held a further 20 per cent. The remaining small holders, about one million, owned the rest of the agricultural land. This situation caused great class conflicts between landowners, small land owners and tenant farmers, which contributed directly to periodic rural unrest in the 1920s-1930s and the revolutionary war for independence (1945-1954) (Kerkvliet 2006).

In 1954, after the defeat of the French at the battle of Dien Bien Phu, the Vietnamese communists took control of North Vietnam. The Geneva Accords effectively resulted in a fragmented Vietnam with two sovereign states - the Democratic Republic of Vietnam in the North, led by the Vietnamese Communist Party, and the Republic of Vietnam, supported by America, in the South. The North and the South developed along two very different paths in terms of politics and economics. The North's economy developed all the characteristics of a Soviet-style socialist centralised economic system, while the South's economy was decentralised and heavily dependent on America.

In the South, the Vietnamese-American government emphasized private property and was in favour of large land owners at the expenses of the peasants (Callison1983; Kerkvliet 2006). This policy continued until 1970, when the government began a redistribution of land and implemented the 'land to the tiller' programme. The result was 
that approximately 1.3 million hectares of agricultural land was redistributed to over one million farmers by the end of 1974 (Pingali and Vo 1992).

In the North, large landowners and rich peasants were publicly denounced as landlords, and their land redistributed to poor and middle class peasants, particularly to those with ties to the Communist Party. By 1956, this programme of redistribution had transferred ownership of substantially all the available land to farmers in a largely equitable manner which benefitted approximately 73 per cent of the North's rural population (Truong 1987, 35). The North also entered a stage of agricultural collectivization.

The initial steps were to establish work-exchange teams (to doi cong), a simple form of agricultural collectivisation, which included the majority of the farmers. This collective economic form was organized on the principle of voluntary participation. Farmers retained ownership of land and equipment and were in control of production on their land but were encouraged to assist each other during periods of peak labour demand by joining seasonal or permanent working teams. The work-exchange teams helped to improve agricultural production during the post-war period. As a result, food output increased 57 per cent with average food per capita of $303 \mathrm{~kg}$ per year. This not only ensured food for domestic consumption but also yielded a surplus for export in1956 and 1957 (Tran 1998a, 32).

Encouraged by the positive results of this 'golden period' (Tran 1998a, 32), the Government decided to accelerate the agriculture collectivisation program throughout North Vietnam. Work-exchange teams were transformed into agricultural cooperatives, starting out at a low level (1958-1960) and advancing to the high level of cooperatives (1960-1972). The low level of cooperatives worked on the principle that farmers also kept their own land, traction animals and equipment but farmed according to the general plan of the cooperative, while in the high level of cooperatives, all land and farm instruments were put under cooperative properties and farmers worked under a unified management (Pingali and Vo 1992).

Initially, the collectivisation movement achieved some success. The stage of low level agricultural cooperatives, between 1959 and 1960, witnessed a sharp increase in the number of cooperatives established. By the end of 1960, 40,422 cooperatives were setup throughout North Vietnam, encompassing over 2.4 million peasant households, accounting for 86 percent of the total households (Tran 1998a, 32). However, this early success was 
short-lived. Between 1962-1975, the average growth in the yield of rice, the most important crop of the country, was only 1.1 per cent per year with negative growth in seven out of fourteen years (FAO 2000 as quoted in Nguyen 2000, 25). The reasons that the system did not function as expected are many. Agricultural cooperatives constrained individual choice and eliminated the economic incentives required for efficient agricultural production and markets. The mandatory collectivisation policies resulted in the removal of private farm ownership, and reduced the economic incentives for farmers to produce and market their crops. These factors ultimately dampened farmers' enthusiasm for work and resulted in both low agricultural efficiency and productivity (Tran 1998b).

\section{Agricultural Cooperatives in the Compulsory Collectivisation Period of 1975-1981}

After the country was reunited in1975, the Communist Party quickly sought to establish a socialist production in the hitherto capitalist-oriented South and thus bring this part of the country in line with the North. The Communist Party outlawed tenancy and enforced agricultural cooperatives in the South. In these cooperatives, the cultivation of crops, the division of labour, and the distribution of the harvest was bureaucratically managed and the state retained the ownership of land. Farmers were subjected to a food obligation policy that was implemented in 1978 and 1979, which required them to sell a quota of grain to the state at fixed prices in exchange for fertiliser, gasoline, bricks, and consumer goods at subsidized prices. Free market prices for grain were eight times higher than state prices while state-supplied goods were usually inferior in quality, insufficient in quantity, and delivered late, which interrupted planting and thereby hurt production (Raymond 2008).

The policy faced with stiff resistance from farmers from the very early stage. The level of success of collectivisation and the forced cooperatives program varied significantly in different regions. According to Tran (1998a, 33), in central of Vietnam in 1978, over 67,000 peasant households participated in cooperatives. By the end of 1980 there were 673,500 households in cooperatives, accounting for 83.8 percent of the number of agricultural households. In the eastern region of South Vietnam, only 1.6 percent of the total peasant households had joined cooperatives by the end of 1978. In the western region, the Mekong delta, the situation was even worse with only 0.2 percent of all peasant households joining cooperatives. Despite all efforts, the government's attempt to use a collective mode of production to increase productivity and achieve a large surplus was 
mostly unsuccessful. By the late 1970s, after two decades of collectivisation, only 10-15 per cent of all farming collectives in the North fulfilled the Communist Party government's standards. About 15 per cent were 'relatively good'. The rest, $70-75$ per cent, failed to reach the government's expectations of cooperatives (Nhu 1979, 42 as quoted in Kerkvliet 2006, 293). During the post war period of 1976-1981, the national rice yield grew by a rate as low as one per cent per year. Vietnam was a major food importer during this period (Nguyen 2000, 25).

\section{Agricultural Cooperatives in the De-Collectivisation Period of 1981 - 1997}

This period was marked by signicant reform in the Vietnamese economy in general and agricultural cooperatives in particular. After the unification, under the socialist economic system, the state and collective sectors, which were highly subsidised by the state budget, were the foundation of the economy. Large-scale private economic organisations were forced or encouraged to join the state or collective sectors. This process effectively eliminated the market mechanism except in small-scale (household) activities. Therefore, it became clear as early as 1977 that the economic strategy was not working, with the economy witnessing steady declines in production and productivity in vital industries, including agriculture (Le and McCarty, 1995: 100). In 1980, Vietnam’s GDP growth rate was -1.6 per cent (Statistical Yearbook 1995). In the same year, food production reached only 69 per cent of its target (Vu 1995, 19). By the mid-1980s, Vietnamese economy was barely sustained thanks to significant assistance from the Eastern bloc (now a burdensome debt for Vietnam). The lowest point was reached in 1985, when a miscalculated currency reform plan was introduced, effectively re-valuing the Dong, in a bid to reduce the amount of money circulating and encourage the import-reliant economy but in fact resulted in an escalating inflation rate. As Wurfel (1993: 23) puts it 'Economic necessity was the mother of [Vietnamese] reformist invention'.

At the Sixth National Congress of the Communist Party in 1986, the Vietnamese government introduced a comprehensive reform program, known as Doi Moi, with the objective of liberalising and deregulating the economy. The agricultural reform in Vietnam actually started before the Doi Moi. On the $13^{\text {th }}$ January 1981, Vietnam introduced the Directive No $100 \mathrm{CT} / \mathrm{TW}$ on 'improvement of contractual activities and extension of product contracts to labour groups and individuals in the agricultural production cooperatives' ('Contract 100' for short) into the agricultural production sector. For the first time since the 
establishment of agricultural cooperatives, the government recognised market forces in the operation of cooperatives. Under the 'contractual' mechanism, cooperatives entrusted land to a member household on a contract. Farmers were responsible for sowing, seedling transplanting, tending and harvesting of the crop (known as the three production links). Subsequent phases in processing and marketing were still the responsibility of the cooperatives. All land and production means were still placed under the management and disposition of the cooperatives. The household had to deliver a quota of food to the state as stipulated in the contract but could use five per cent of their land privately and sell the surplus product on the market (Beresford 1999, 13). The new system enabled individual farm households to cultivate more independently and to be responsible for providing the contracted amount of output to the state (Pingali and Vo 1992; Nguyen 2000).

The initial reform had positive effects on agricultural production. National rice production increased from 226 kilograms per person in 1981 to 256 in 1982 and annual harvests of food crops rose from 15.0 million tons in 1981 to 17.8 million tons in 1984 (Raymond 2008, 52). However, the growth occurred mainly in the first year after 'Contract 100' was implemented. After 1982, the country again experienced a continual decrease in the rice yield growth rate from year to year, which became negative in 1987. Pingali and Vo (1992) argued that the main reasons for this failure was the cumbersome, top down planning approach in production, the frequent failure of the state to buy all the contracted products from farmers due to limited funds, and the lack of security in land tenure resulting in insufficient investments at the farm level. Fundamentally the cooperative model was still based on collective ownership, centrally run management and the uniform distribution of products based on workdays. Collective farmers were paid 'work points', which were converted into amounts of agricultural products such as rice and other food and occasionally money through an elaborate assessment method that assured everyone a basic share of each collective’s net income but provided little reward for productivity and innovation (Kerkvliet 2006).

In response to the problem of critically low agricultural production in the second half of the 1980s, the Vietnamese government promulgated Resolution No. 10 NQ/TW in 1988 (All Around Renovation of Economic Management in Agriculture), which created fundamental changes to the agricultural sector and to rural development. The significance of Resolution No.10 was the full recognition of the market mechanism in the operations of 
cooperatives. The Resolution recognised farming households as the main units of agricultural production and further empowered farmers to manage all stages of production. The only obligation of the peasants and of the cooperatives to the state was to pay agricultural taxes (Pingali and Vo 1992). Resolution No. 10 was strongly supported by the Land Law 1993 and its revisions in 1998 and 2000, which provided security in land use rights for farmers. The main feature of the land reform policies was the privatisation of land-use rights with farmers granted 25 years of land use right for rice and other annual crops and 50 years of land use right for perennial crops (ownership right to the land, however, remained with the State) (Pham and Nguyen 2005).

\section{Agricultural Cooperatives in the Neo-Collectivisation Period Since 1997}

Although cooperatives continued to exist, their major traditional tasks in agricultural production were no longer needed (Wolz and Pham 2010). Many of them failed to provide the necessary services to the newly-established family farmers, especially input supply (Sultan and Wolz 2012). In this context, the Cooperative Law was introduced in 1997. According to Sultan and Wolz (2012), the Cooperative Law was developed based on the basic principles of the international cooperative movement and reflected user-centred policies and voluntary membership. Compared with the old model, the new model focuses more on providing services and marketing activities to its members (Table 1).

\section{Insert Table 1 here}

There were three options for previously existing agricultural cooperatives under the new law (Wolz and Pham 2010). They included: (i) the conversion of the old style agricultural cooperatives into viable agricultural service cooperatives that had to be newly-registered; (ii) the dissolution of old style agricultural cooperatives; and (iii) the formation and registration of new agricultural service cooperatives. There was an initial lack of interest from cooperatives in the conversion process and it took much longer than anticipated to finalise (Sultan and Wolz 2012).

Since the new Cooperative Law became effective in 1997, it has been revised twice in 2003 and 2012. The legal environment has been improving gradually to encourage the formulation and development of the new model of cooperatives. The second revision of the Cooperative Law in 2012 for example simplified the administrative procedures for cooperatives including 
the registration, setting up of branches and closure of cooperatives. The time it takes to register a cooperative was cut from 15 days to 5 days. This aimed to facilitate the registration of new cooperatives, and expansion and even closure of current ones.

The development of the cooperatives has been further supported in recent years with the establishment of the National Cooperative Assistance Fund in 2006. These funds were established to provide credit to cooperatives in their respective provinces and to help them expand business activities. Furthermore, since 2002 the concept of contract farming has been strongly supported by the Vietnamese government. There has been an increase in the number of agricultural cooperatives participating in contract farming since the promulgation of Decision 80 in 2002 which aimed to promote agricultural transformation from subsistence farming to a commercialised and export-oriented agricultural sector. This decision, often known as "four-party" contract, promotes cooperation between the state, farmers, research institutions and enterprises (Asian Development Bank 2005). It aims to improve procurement of agricultural cooperatives' products, and to promote technology innovation in the rural economy. Neverthelesss, the model has not been very sucessful due to lack of trust, lack of professionalism, mismanagement of contract, lack of cooperation among parties. There is a need for clearly defined roles of the four parties, good governance of the contract and an effective value chain.

\section{Performance of the New Agricultural Cooperatives}

As of $31^{\text {st }}$ December 2010, there were 6,302 agricultural cooperatives (GSO 2012, 58). This represented a decline of 12.9 per cent during a five-year period from 2006 when the number of agricultural cooperatives was 7,237. The fall in number of agricultural cooperatives could be due to the closure and exit of inefficient cooperatives during the period when the Vietnamese economy experienced a downturn with GDP growth dropping from 8.23 per cent in 2006 to 5.89 per cent in 2011. In addition, the global financial crisis contributed to a fall in demand of Vietnamese agricultural products in international markets and as a result cooperatives also suffered. In terms of economic performance, the capital-employee ratio in agricultural cooperatives reached 59.8 million Vietnamese dong (VND) in 2010 (equivalent to about 3,000USD in 2010), which was an increase of 13.9 per cent compared to 2005. However, average income for agricultural cooperative members is still very low, standing at only 201,000VND (about 11 USD) a month in 2010. 
Figures from the 2011 Rural, Agricultural and Fishery Census revealed that agricultural cooperatives employed 136,100 permanent workers in 2010, achieving a growth rate of 7.8 per cent compared to 2006 (GSO 2012, 59). Of the permanent workers about 128,000 are members of the cooperatives. As such, cooperative members made up 94.1 per cent of the total employment in the sector. The remaining 5.9 per cent of the workers are employed outside the cooperatives. The average size of a cooperative is about 22 workers of which 20 are members (GSO 2012, 59). Hence their size is relatively small and it is difficult to achieve economies of scale. Nevertheless, the average size of a cooperative has risen by 24 per cent compared to the average size in 2006. Most of the workers employed in the agricultural cooperatives were between the ages of 35 to 55 accounting for almost 70 per cent of the employment in 2012. The second largest age group in the agricultural cooperatives is the 15 34 age group with a share of about 18 per cent (GSO 2012, 59). The expanding size of cooperatives and the relatively young ages of cooperatives' members appear as encouraging signs that potentially show the popularity of this economic organisation form with the new generation.

In sum, as suggested by the insitutionalist theory, the government has played an extremely important role in the formation and development of Vietnamese agricultural cooperatives. This form of economic organisation has undergone significant transformation since 1954. The statistics show a picture with some encouraging sights for the whole sector. Questions remain, however, on what happens at the micro-level (cooperative level). These questions include: How have the changes in the government's policies impacted on the daily operations of agricultural cooperatives? How do government agencies support the operations of agricultural cooperatives? How will the agricultural cooperatives evolve in the future?

\section{Research Methodology}

A case study approach is used in this study because of its suitability for exploratory and descriptive research, and studies where the phenomenon under investigation is very much socially and contextually situated (Yin 1994; Marshall and Rossman 1995). Case studies enable researchers to observe phenomena as they occur in their settings, a feature that allows surrounding social and structural intricacies to be exposed and unravelled (Yin 1994). This essentially provides a more accurate conception of events and behaviours, and a more 
comprehensive understanding of the associations that influence the phenomenon in question (Eisenhardt 1989; Orum et al. 1991).

Two agricultural cooperatives were chosen to study, coded in this research as AG1 and AG2 (Table 2). Some criteria govern the choice of cooperatives: (1) the size of the cooperatives priority is given to cooperatives that have a larger number of members; (2) age of the cooperatives. AG1 represents old cooperatives that have a long history dating back to pre-Doi Moi period. It has survived many waves of changes in government policies and thrived in the new context. Meanwhile AG2 represents the newcomers that have only been established in the last decade; and (3) accessibility to the cooperatives.

\section{Insert Table 2 here}

Interviews were the primary source of research data, and the focal point of the empirical research element of this work. There were two groups of interviewees: those inside the cooperatives and outside the cooperatives. The first group included the Chairman and/or Vice Chairman and members of the cooperatives (at least two at each cooperative). It was considered necessary to conduct interviews at two levels to cross check the information as well as to examine whether the policies stated and described by the board of management were indeed implemented at lower levels of the organisations. There was also a need to corroborate the information provided, and thereby reduce hidden bias and aid reliability.

The second group included government officials from the Cooperative Department at the Ministry of Planning and Investment and the provincial Departments of Agriculture and Rural Development (DARD). These departments have played a very active role in implementing Decision 80, by supporting the establishment of cooperatives and facilitating the signing of contract farming between cooperatives and agricultural product purchasing companies. Interviewing personnel outside the enterprise context was considered vital, given that one of the aims of the research is to understand the role of the government and its agencies in the development of agricultural cooperatives.

Interview questions were organised into six themes: history of the cooperatives, profiles of the households, their agricultural production, the households' current use of cooperative services, the respondents' assessments on the services provided by cooperatives and any factors that hinder or facilitate the operations of cooperatives. Semi-structured interviews 
were conducted on site in 2004 and over the phone in 2013 to update data. The length of the interviews ranged from 30 to 80 minutes. In total, 17 interviews were carried out. The distribution and characteristics of the intervieweeare depicted in Table 3.

\section{Insert Table 3 here.}

Ethical considerations were taken into account in this research. Throughout the research process, steps were taken to ensure key interviewees were protected particularly in terms of their privacy and confidentiality. All participants were assured the information they provided would only be used to fulfil the aims of research, and were informed of their right to withdraw from the study at any time for any reason.

\section{Empirical study}

\section{AG1}

AG1 was established during the period of central planning in 1978. During the compulsory collectivisation period, the whole production process from the cultivation stage to the distribution of the harvest was bureaucratically managed. The management of labour extended even to working hours which were announced by the village bell. Regardless of their productivity, farmers were required to sell a quota of grain to the state at fixed prices. In the de-collectivisation period, following Contract 100 issued in 1981, land was distributed to the households according to family size. Land that was brought in to the cooperative by households during the collectivisation phase was also returned to them. In this period, the role of agricultural cooperatives was reduced and households were recognised as the primary units of production.

The Cooperative Law 1997 established the foundation for the old style agricultural cooperatives to convert into membership-oriented service providers. AG1 was revived and has successfully diversified services to its members, including input supply (fertilisers, pesticides and seeds), irrigation services, land preparation services, field protection services, marketing and selling of output and development of extra income-generating activities (such as poultry farming, handicraft production, construction services, ice factories, mixing of animal feeds). Irrigation services, in particular the maintenance of the distribution canals and the pumping of water, was considered one of the most important services offered by AG1 as 
it required a level of cooperation between farmers. The fees and contributions for irrigation services was $450 \mathrm{~kg}$ paddy/ha per year. To operationalize this service, AG1 bought water from the irrigation companies and then provided water to internal channels leading to the rice fields. It collected a fee from farmers for this service.

AG1 was also involved in the signing of contract farming with purchasing companies. Based on farmers' production abilities of a specific agricultural product, the cooperative looked for markets for these products and represented farmers in contract negotiations and agreements with the purchasers. After signing the contracts with the companies, the cooperative established subsequent contracts for agricultural product procurement with its members and as such the cooperative played the intermediary role in this process.

The interview with the commune authorities revealed that there was an emergence of linkages between cooperatives. AG1 formed linkages with other cooperatives in nearby localities and has maintained a regular exchange of information on market conditions, prices of materials and commodities, and sub-contracting prices in consumption contracts. This has helped to enhance the competitiveness of the cooperatives.

According to its Chairman, AG1 is now a strong and viable organisation. It comprises over 600 households with more than 3,000 family members, and controls over 500 ha of agricultural land. However, total capital of the cooperative is still very low, about 2,175 million VND (87,000 USD). The operating capital for running service activities is even lower, accounting for only 25 percent of total capital or just 21,750 USD. The rest is the value of fixed assets. The Chairman of AG1 noted that the low level of operating capital has impeded the implementation of service provision to members of the cooperative.

\section{AG2}

Compared to AG1, AG2 is a 'newcomer' having been established in 2003. Interviewed farmers noted that before joining the cooperative, they operated as individual households. Every morning, farmers brought their vegetables to a local market to sell. If the vegetables were accepted by vegetable stall owners, farmers would sell all their products at a wholesale price; otherwise they would sell them to consumers in the market. If they could not sell all their vegetables, they would bring them back to the village and sell them to other households as poultry food. Farmers did not maintain a long term plan for crop selection, rather they 
planted based on the current price in the market. If a particular vegetable price was low, its cultivation would be stopped and a different vegetable crop would be sown. Therefore, their income from vegetables was very low and highly dependent on the fluctuations in market prices. This led to most farmers lacking surplus capital and prevented them from purchasingpesticides and fertilisers. Farmers did not pay attention to cultivation techniques to improve output because they were either unaware of or lacked information about market demand.

By 2002, purchasing companies, such as supermarkets and food catering companies came to the province to propose a plan to purchase clean vegetables on a large scale. This triggered authorities into considering the establishment of a co-operative to meet the projected demand. AG2 had a very modest start with 20 members, each of whom contributed a total amount of 200,000 VND (roughly 8 USD), mostly to build a cooperative office (on the borrowed land of the commune committee) and for other administrative costs. The management board of the cooperative initially had three people who worked without salary.

From the outset, AG2 was actively supported by the provincial Department of Agriculture and Rural Development (DARD). For example, the DARD distributed a budget of nearly 100 million VND (4,000 USD) to support the cultivation of clean vegetables by providing training on cultivation techniques to all members of the cooperative. Most importantly, DARD facilitated the signing of contract farming between the cooperative and agricultural product purchasers. Previously, the cooperative focused on production, and passively waited for purchasers to come to them. Based on their wide networks, DARD was in touch with a large number of potential purchasers and acted as a link between these companies and AG2. At present, there are 36 companies including both small retail stores and large purchasing companies that have signed contracts with AG2 for the supply of vegetables.

The terms and conditions in these contracts specify that the cooperative is responsible for vegetable origins and their quality, and that government food safety standards will be strictly adhered. The board members of the cooperative thus monitor closely the cultivation process at each household member to ensure the quality is met. Also AG2 is responsible for delivering the products in accordance with the terms of the contract relating to quantity, time and place of delivery. Selling prices are set at the market level. However, the cooperative offers purchasers preferential conditions such as deferred payment after the delivery of the products. If the price set in the contract is higher than the market price due to price 
fluctuations, the purchasers have the right to deduct the difference during the next trading round.

Interviewed farmers believed that they now have much better knowledge of cultivating, harvesting, packaging, categorising and transporting their products as well as better access to market information. Therefore, their incomes from clean vegetable have significantly improved. Members are committed to the cooperative and always give priority to the cooperative when it comes to selling their products. They appreciate that their products are bought at a fair market price and that they are shielded from fluctuations in market demand, which was a big concern for farmers prior to the cooperative. The Chairman shared that cooperative membership has increased from 20 persons in 2003 to 34 persons currently. According to him, on average, the cooperative members earn around 50-70 million VND per ha (2,000 - 2,800 USD), compared to 20 -50 million VND per ha (800 - 2,000 USD) when they operated individually prior to 2003.

\section{Discussions}

Smallbone and Welter (2001) observed that the dominant feature influencing the nature and pace of entrepreneurship development in transition economies is the external environment, which, in some cases, appears hostile in social, economic and political terms. In addition, the social context inherited from the former socialist period appears to affect both the attitudes and behaviour of entrepreneurs and the attitudes of society at large towards entrepreneurship. Like the private sector, agricultural cooperatives in Vietnam have encountered numerous problems from the lack of enterprise culture during the socialist period. In addition, the support infrastructure has not always been sufficient to help them to overcome such problems. The Vietnamese economy has market institutions and infrastructures that are largely undeveloped (Le et al., 2006). They face higher transaction costs and have limited access to credit and other inputs.

Transition economies have experienced a combination of privatisation, entry of new private firms and fundamental changes in the legal, institutional and regulatory systems. Vietnam has experienced similar changes which improve the overall business environment including the legal framework for for agricultural cooperatives. The development of the new model of cooperatives in Vietnam since the Law on Cooperatives was adopted in 1997 has been supported by different agencies in Vietnam. They include the Cooperative Department at the 
Ministry of Planning and Investment, which is responsible for formulating strategies and policies for the development of cooperatives in Vietnam; the Vietnam Cooperative Alliance, which aims to support, promote and represent cooperatives at different policy levels; and the Department of Cooperatives and Rural Development at the Ministry of Agriculture and Rural Development, which solely focuses on agricultural cooperatives. The activities of these key agencies aim at promoting the establishment of new cooperatives, training to existing cooperative staff, trade promotion, and upgrading facilities, equipment and technology to expand production. Government policy documents indicate that the Government intends to support cooperatives by providing (i) incentives for the establishment of cooperatives; (ii) training for management staff; (iii) access to land and premises; (iv) access to credit; (v) tax cuts; (vi) trade promotion; (vii) technology and extension services; (viii) facilities and equipment; and (ix) establishment of the cooperative development fund (Government of Vietnam, 2005). The government allocates a portion of the budget to different agencies to carry out activities in the above areas according to a yearly plan (MPI 2012).

The case studies indicate that appropriate support from the government can greatly enhance the performance of agricultural cooperatives. Government policy has had a strong influence on farmer cooperative establishment and development. This finding is similar to studies of farmer cooperatives development in China, a country that shares many similarities to Vietnam in terms of historical traditions, domestic economies, which are predominantly agrarian and rice cultivating, and the transition from formerly centralplanned into increasingly market-oriented economies (see for example Garnevska et al. 2011). However, it is contrary to Bekkum's (2001) research findings that show that government policy has a limited impact on cooperative development in liberalized economies.

Although an extensive range of support policies are available to cooperatives, there is still a problem with their implementation. The policies have not been consistently implemented across agencies or at different administrative levels. Therefore, the support seems to be dependent on the efforts of government officials or cooperative leaders. For example, it is always difficult to get access to credit for cooperatives to invest and expand their production but a personal relationship between the cooperative manager and local government officials can make it easier. Another issue is the lack of targeted support measures for sectors and subsectors. The high level support programs have not been effective in meeting the needs of 
specific sectors. For example, training courses are provided in the area of product marketing but not at the level of marketing of agricultural produce.

Agricultural cooperatives account for more than half of the existing cooperatives in Vietnam. They have contributed significantly to creating employment and income for their own members and additional workers. Despite the decline in the number of agricultural cooperatives in the last 10 years, they still provide a large number of employment. However, the share of the collective sector in general and agricultural cooperatives in particular in GDP is still limited. The collective sector contributed only 5.2 per cent to GDP in 2011 making it the smallest sector in the economy of Vietnam (GSO 2012). Furthermore, the size of agricultural cooperatives in Vietnam is relatively small with 20 members on average for each cooperative (GSO 2012, 59). Thus, they could increase their size to reach a more efficient scale.

Future development of cooperatives in Vietnam need to focus on supporting cooperatives to expand, become more diversified in their activities, improve management staff capacity and worker skills. In the agriculture sector, provinces are asked by the Ministry of Agriculture and Rural Development to identify models that work in different sub-sectors and in different types of products and services so that they can be replicated in similar contexts (Nguyen 2012). Efforts are being focused on innovating, developing and improving the efficiency of current agricultural co-operatives. In addition, the development of agricultural cooperatives with operations in production, business, and general services as well as specialized agricultural cooperatives are being encouraged by the Government. Increasingly, agriculture cooperatives attempt to offer quality produce with better value to not only the local market but also export markets.

\section{Implications}

\section{Theoretical implications}

As discussed in the literature review, an institutionalist approach is a very useful tool to analysis firms' behaviours. It highlights the causal relation between institutional arrangements and firms' structure and characteristics. This study acknowledges the contributions of the institutionalist approach. However, it is argued that the institutionalist analysis comes short in investigating transitional economies and the form of economic 
organisations which exist within them as it fails to convey a sense of 'changefulness' of a business system (Martin and Beaumont, 2001). Taking into account profound changes and volatility within the Vietnamese business system in the last three decades and in the external environments (the process of regionalisation and globalisation), this research sees the need to integrate the notion of institutional dynamics into the current 'static' institutionalism (Thelen and Steimo, 1992).

Furthermore, it is clear that in the context of Vietnam, despite the availability of extensive institutions set out to govern and and support agricultural cooperatives, their successful development is not guarranteed. Formal institutions could not make agricultural cooperatives work in the earlier periods. Many initiatives failed or encountered strong resistance because without the basic principles of voluntary participation, there was a lack of participation from cooperative members. In addition, formal institutions alone do not automatically lead to the implementation of supporting policies at the local level to benefit agricultural cooperatives. Thus, an institutionalist approach which solely relies on a rational assumption of a direct link between institutional arrangements and the development of business organisations (Maurice et al., 1996; Hollingsworth and Boyer, 1997; Lane, 1992; Whitley, 1999) will fail to fully explain the success or failure of cooperatives as demonstrated in this study. An integrative approach that highlights the roles all the stakeholders, their bargaining powers and the interaction amongst them is needed in any analysis of firms' behaviours. Furthermore, it is not only institutioanl arrangement at national level needs to account for the development of organisations, their agencies at provincial and local levels are also extremely important in this process.

\section{Practical implications}

Vietnam's experience with the transformation of the cooperative sector could offer several useful lessons for other economies attemping to develop agricultural cooperatives. First, the formation of cooperatives should be based on voluntary participation. The coercive nature of agricultural cooperatives in earlier periods in Vietnam resulted in the limited success of the cooperatives as it did not provide incentives for members to perform and deliver. Second, new policy and regulation to support cooperatives do not automatically lead to growth in the number of cooperatives. In fact, the number of cooperatives established should not be seen as a success factor of government policy . Administrators shoud also focus on quality and efficiency of the newly formed cooperatives and not only on growing the number per se. 
Third, policy implementation has to be monitored closely as it is the key to delivering intended outcomes and this is particularly important at the local level. It is important to make timely adjustments that are relevant to sectoral and local conditions to support the growth and development of cooperatives. Fourth, the transition towards a market economy requires cooperative managers to upgrade their business management knowledge and skills which had been poorly developed during the central planning period and are not suitable in the current situation. Fifth, diversifying products, upgrading technology, introducing innovation have the potential to increase efficiency and this will help cooperatives to add value, become more competitive and move up the value chain. Finally, policymakers and cooperative managers will need to set priorities for each period in the development of cooperatives so that their limited and valuable resources can be maximised to achieve their respective goals for each period.

\section{Limitations}

This research has been conducted within a definite time scale and is subject to some limitations in research methodology and scope. First, adopting a qualitative method, it does not rely on a large sample as with a survey approach. The rationale of choosing the qualitative method is provided in the methodology section, and the approach has been proven to be a sharp tool to solve the research questions posed by this research; nevertheless, broad generalisation to a large number of cooperatives can be problematic. Second, the study concentrates only on one industry. If the research had encompassed other industries, the outcomes would have consisted of a more complete picture of cooperatives across industries. Lastly, the focus of this study is on two successful cooperatives, thus unsuccessful cooperatives are excluded from this study. An analysis of unsuccessful firms could have provided valuable lessons on the management of cooperatives, especially in the context of transforming economies.

\section{Conclusion}

Vietnamese agricultural cooperatives have witnessed great changes and transformation in the last six decades and are still in a transformation phase, whereby there is a slow conversion of the old-type cooperative to the new cooperative type guided by the Cooperative Law. The successful cases of agricultural cooperatives outlined in this study suggest that the new model 
of agricultural cooperatives could work well in the context of a transitioning economy. Most agricultural cooperatives have been able to provide valuable services to their members, especially input supply, marketing and selling of agricultural outputs. Some cooperatives have diversified their services by mobilising investment capital, developing production planning, building market share, creating jobs, and achieving high returns (Phuong 2008).

Using an institutionalist approach, this research argues that the legal environment and appropriate government policy and support are extremely important for the successful development of cooperatives. The Cooperative Law 1997 and its revisions in 2003 and 2012 have set up the legal framework to encourage the formulation and development of commercialised agricultural cooperatives at the national level. However, the two case studies presented here have demonstrated that not only national institutions' influences but also those of the 'human agencies' at local and organisational level are equally important. 
Table 1: Basic information on agricultural service cooperative development in Vietnam

\begin{tabular}{|l|l|}
\hline $\begin{array}{l}\text { Development periods after de- } \\
\text { collectivisation }\end{array}$ & Main characteristics \\
\hline $\begin{array}{l}\text { 1986-1996: collective farms still operated as } \\
\text { service providers, }\end{array}$ & $\begin{array}{l}\bullet \text { Basic services to farmers: extension, input } \\
\text { supply, irrigation, electricity; no marketing. } \\
\bullet \text { Government promotion, but almost no } \\
\text { financial support. }\end{array}$ \\
\hline $\begin{array}{l}\text { Since 1997: Cooperative Law became } \\
\text { effective: recognized as registered legal } \\
\text { entities under the law; transformation of still } \\
\text { operational cooperatives ('old style' into 'new } \\
\text { style'), set-up of new ones from scratch }\end{array}$ & $\begin{array}{l}\bullet \text { Better services: extension, input supply, } \\
\text { irrigation, electricity, basic marketing } \\
\text { activities. } \\
\bullet \text { Limited support from government. }\end{array}$ \\
\hline
\end{tabular}

Source: Adapted from Son, 2009; Wolz and Pham, 2010

Table 2: Case Study Profiles

\begin{tabular}{|l|l|l|}
\hline & AG1 & AG2 \\
\hline Year of establishment & 1978 & 2004 \\
\hline Location & Tien Giang province & Vinh Long province \\
\hline Product & $\begin{array}{l}\text { rice (main product); poultry } \\
\text { farming, handicraft production, } \\
\text { construction services, ice } \\
\text { factories, mixing of animal feeds } \\
\text { (other products) }\end{array}$ & $\begin{array}{l}\text { clean vegetables (green } \\
\text { vegetable, fennel, roots and } \\
\text { fruits) }\end{array}$ \\
\hline Area of cultivation & 500 ha & 85 ha \\
\hline Number of members & 3,000 & 34 \\
\hline
\end{tabular}

Table 3: Interviewee Distribution and Characteristics

\begin{tabular}{|l|l|l|l|}
\hline & AG1 & AG2 & Government Official \\
\hline Management Staff & $\begin{array}{l}\text { 2 (Chairman } \\
\text { and Deputy } \\
\text { Chairman) }\end{array}$ & $\begin{array}{l}3 \text { (Chairman, } \\
\text { Vice Chairman } \\
\text { and Chief } \\
\text { Accountant) }\end{array}$ & $\begin{array}{l}\text { 3 (1 from the Cooperative } \\
\text { Department at the Ministry of } \\
\text { Planning and Investment, and } \\
\text { 2 from the provincial } \\
\text { Departments of Agriculture } \\
\text { and Rural Development) }\end{array}$ \\
\hline Cooperative Member & $\begin{array}{l}4 \text { (2 female and } \\
2 \text { male) }\end{array}$ & $\begin{array}{l}5 \text { (2 female and } \\
3 \text { male) }\end{array}$ & \begin{tabular}{l} 
N/A \\
\hline
\end{tabular}
\end{tabular}




\section{References}

Asian Development Bank. 2002. Program Performance Audit Report on the Agricultural Sector Program (Loan 1340-VJE[SF\}) in the Socialist Republic of Vietnam. Manila, ADB (Report PPA: VIE 25325).

Bekkum, O.-F. v. 2001. Cooperative models and farm policy reform: exploring patterns in struc-ture-strategy matches of dairy cooperatives in regulated vs. liberalized markets. Assen: Van Gorcum.

Bui, D.T. N. 2003. 'Vietnam'. In Agrarian Reforms and Agricultural Productivity, edited by M. G. Chaudhry, 199-208. Report of the APO Study Meeting on Agrarian Reforms and Agricultural Productivity. Tokyo: the Asian Productivity Organization.

Callison, C. S. 1983. Land to the Tiller in the Mekong Delta. Berkeley, CA: Center for South and Southeast Asia Studies, University of California.

Chloupková, J. 2002. European Cooperative Movement. Background and Common Denominators. Working paper 24204 from the Royal Veterinary and Agricultural University, Department of Economics and Natural Resources, Copenhagen.

Cohen, M. 2001. “Vietnam - Reluctant Cooperation. The Government's New- Style Agricultural Cooperatives Meet Resistance From Many Farmers And Jack The Preconditions Vital For Success”. Far Eastern Economic Review, Hong Kong, 22 November 2001, 28-29.

Foerster, E., and Nguyen, T. H. 1999. "Technical Agriculture and Agroforestry Options for Sustainable Development Promoted by SFDP in the Song Da Watershed". Working Paper Number 5, Social Forestry Development Project Song Da, Hanoi.

Garnevska, E., Liu, G. and Shadbolt, N. 2011. 'Factors for Successful Development of Farmer cooperatives in Northwest China'. International Food and Agribusiness Management Review. Volume 14, Issue 4.

General Statistics Office (GSO). 2012. Results of the 2011 Rural, Agricultural and Fishery Census. Hanoi: Statistical Publishing House. 
General Statistics Office (GSO). 2013. Statistical Yearbook of Vietnam. Hanoi: Statistical Publishing House.

General Statistics Office (GSO). 2013. Report on Initial Results of the 2012 Establishment Census. Hanoi: Statistical Publishing House.

Government of Vietnam. 2005. Decree No 88/2005/ND-CP on Policy to Support and Promote Cooperatives issued on 11 July 2005

Herrigel, G. 1996. Industrial constructions: the sources of German industrial power, New York: Cambridge University Press.

Hollingsworth, R.J. and Boyer, R. 1997. 'Coordination of economic actors and social systems of production', in Hollingsworth, R.J. and Boyer, R. (eds.) Contemporary capitalism the embeddedness of institutions, the USA: Cambridge University Press.

Ho, B.D. 2012. Total Factor Productivity in Vietnamese Agriculture and Its Determinants. PhD thesis, University of Canberra: Faculty of Business, Government \& Law.

International Co-opeative Alliance (ICA). 2013. 'Cooperative Identity, Values \& Principles'. Available at http://ica.coop/en/what-co-op/co-operative-identity-values-principles. Assessed on $10^{\text {th }}$ November 2013.

Kaiser, K. 1997. Proposals to Increase the Efficiency and Effectiveness of Extension Services Supported by SFDP Song Da in the Districts of Yen Chau and Tua Chua. Consultancy Report Number 07, Social Forestry Development Project Song Da, Hanoi, March 1997.

Kerkvliet, B. J. T. 1994. "Village State Relations in Vietnam: The Effect of Everyday Politics on Decollectivisation”. Journal of Asian Studies 54 (May): 396-418.

Kerkvliet, B. J. T. 1998. "Wobbly Foundations: Building Cooperatives in Rural Vietnam”. South East Asia Research 6 (November): 193-251.

Kerkvliet, B. J. T. 2005. The Power of Everyday Politics: How Vietnamese Peasants Transformed National Policy. Cornell University Press, Ithaca.

Kerkvliet, B. J. T. 2006. “Agricultural Land in Vietnam: Markets Tempered by Family, Community and Socialist Practices”. Journal of Agrarian Change. 6(3): 285-305. 
Lane, C. .1992. 'European business systems: Britain and Germany compared', in Whitley, R. (ed.) European business systems firms and markets in their national contexts,, SAGE publications.

Le, D.D. and McCarty, A.1995. "Economic Reform in Vietnam: Achievements and Prospects”. In Asian transitional economies edited by Naya, S.F. and Tan, J.L.H. Institute of Southeast Asian Studies, Singapore.

Le, N. T. B., Venkatesh S. and Nguyen, T. V. 2006. "Getting Bank Financing: A Study of Vietnamese Private Firms." Asia Pacific Journal of Management, 23(2):209-227.

Maurice, M, Sellier, F., and Silvestre, J.J. 1986. The social foundations of industrial power, Cambridge, Mass.: MIT Press.

Marshall, C.and Rossman, G. 1995. Designing Qualitative Research. 2nd edition, California: Sage.

Ministry of Planning and Investment (MPI). 2012, Report on the Situation Regarding Collective Economic Sector in 2011 and Plan for 2012, Hanoi, Ministry of Planning and Investment (MPI).

Moise, E. 1983. Land Reform in China and North Vietnam. University of North Carolina Press, Chapel Hill.

Nguyen, T.Q. 2000. “Farmers’ Training and the Adoption of Upland Agricultural Technologies in the Black River Watershed, Northwest of Vietnam”. Master thesis, Department of Agricultural and Resource Economics, the University of Arizona.

Nguyen, T.H. 2003. “The Reforms in Vietnam's Agriculture: Achievements and Problems". Paper prepared for the Workshop Transformation of the Agricultural Sector in the Transition Economies: Lessons for North Korea. Seoul, Korea, 17-18 December 2003, Conference Proceedings, Seoul, KREI, 117-153.

Nguyen, D.K. 2012. “Some Development Solutions for Agricultural Co-Operatives in Vietnam”. Speech by Deputy Minister of Agriculture and Rural Development of Vietnam at 
the $9^{\text {th }}$ Asia - Pacific Co-operative Minister Conference, 27 February - 1 March, 2012 Bangkok.

Nguyen, M. D., 2011, Characteristics of Agricultural Cooperatives and Its Service Performance in Bac Ninh province, Vietnam, Journal of International Society for Southeast Asian Agricultural Sciences, 17(1): 68-79.

Nguyen, M.T. 2011. “Cooperative Development in Vietnam: Success and Challenges”. Presentation at UN Export Group Meeting on Cooperatives in Social Development, 3-6 May 2011, Ulaanbaatar.

Nguyen, V.T. 2007. “Agricultural Cooperatives in Vietnam: Innovations and Opportunities”. Paper presented at the international conference Agricultural Cooperatives in Asia: Innovations and Opportunities for the 21st Century. Seoul, National Agricultural Cooperative Federation (NACF), 11-15 September 2007.

Parnell, E. (1992). A New Look at Cooperatives and Their Role in Developing Countries. Small Enterprise Development. Volume 13, No 1.

Pham D.H and Nguyen C.H. 2005. “Reforming Vietnam’s Legal Institution”. In The Vietnamese Economy and Its Transformation to an Open Market System” edited by Alpert, W.T. Chapter 7, 128-142. USA: M.E. Sharpe.

Phung, Q. C. 2008. “Roles and Functions of Cooperative and Rural Producer Organisations in Vietnam”. Presentation at Rural Institutions and Sustainable Livelihoods Workshop, 10 11 April 2008, Addis Ababa.

Pingali, P. L., and Vo, X. T. 1992. "Vietnam: Decollectivisation and Rice Productivity Growth”. Economic Development and Cultural Change, 40(4):697-718.

Rankin, M. and Russell, I., 2005, Building Sustainable Farmer Cooperatives in the Mekong Delta, Vietnam: Is Social Capital the Key? Paper presented at the International Conference on Engaging Communities, 14 - 17 August 2005, Brisbane.Ravallion, M., and Walle, D. v. d. 2003. “Land Allocation in Vietnam’s Agrarian Transition”. Policy Research Working Paper 2951, the World Bank. 
Ravallion, M. and van de Walle, D. 2003. “Land Allocation in Vietnam’s Agrarian Transition: Part I, Breaking up the Collective Farms”. World Bank Policy Research Working Paper, January.

Raymond, C. 2008. "No Responsibility and No Rice: The Rise and Fall of Agricultural Collectivisation in Vietnam”. Faculty and Staff - Articles \& Papers. Paper 21. http://digitalcommons.salve.edu/fac_staff_pub/21. Assessed on 23rd July 2013.

Smallbone, D. and Welter, F. 2001. "The Distinctiveness of Entrepreneurship in Transition Economies." Small Business Economics, 16(4): 249-262.

Statistical Office of Ho Chi Minh City. 1995. Statistical Yearbook, 1995. Hanoi Publishing House.

Sultan, T. and Wolz, A. 2012. “Agricultural Cooperative Development in China and Vietnam since Decollectivisation: A Multi-Stakeholder Approach”. Journal of Rural Cooperation, 40 (2): 239-257.

Tran, T.Q. 1998a. “Economic Reforms and Their Impact on Agricultural Development in Vietnam”. ASEAN Economic Bulletin, 15(1).

Tran, T.Q. 1998b. Vietnam's Agriculture: The Challenges and Achievements. Institute of Southeast Asian Studies.

Truong, Q. 1987. Agricultural Collectivisation and Rural Development in Vietnam: A North/South Study, 1955-1985. Amsterdam: Vrije Universiteit te Amsterdam.

Vietnam Food Association. 2012. "Yearly Export Statistics 2012”.

http://www.vietfood.org.vn/en/default.aspx?c=108\&n=6105. Assessed on $12^{\text {th }}$ August 2013.

Vietnam, Socialist Republic of, The Communist Party. Chi Thi 100-CT/TW Ngay 13/01/1981 cua BCH TW Dang ve Cai Tien Cong Tac Khoan, Mo Rong Cong Tac "Khoan San Pham den Nhom va Nguoi Lao Dong” trong HTX Nong Nghiep.(The Directive Number 100-CT/TW of the Central Communist Party Dated January 13, 1981 on Improvement and Expansion of "Product-Based Contract to Individual and Group of Laborers” in Agricultural Cooperatives). Hanoi, January 1981. 
Vietnam, Socialist Republic of, The Government. Nghi Dinh cua Chinh Phu so 13/CP Ngay 02/03/1993 Ban Hanh Ban Quy Dinh ve Cong Tac Khuyen Nong. (The Decree Number 13/CP of Government Dated March 2, 1994 on Agricultural Extension Regulation). Hanoi, March 1993.

Vu, T.A. 1995. “Economic Policy Reform: An Introductory Overview’. In Vietnam in a Changing World, edited by Nørlund, I., Gates, C.L., Vu, C.D. Curzon Press.

Whitley, R. 1999. How and why are international firms different? The consequences of crossborder managerial coordination for firm characteristics and behaviour, Presented to Sub theme 3 "Business System In Their International Context” of the 15th EGOS Colloquium held at the University of Warwick, 4th - 6th July 1999.

Wolf, E.R. 1999. Peasant Wars of the Twentieth Century. The University of Oklahoma Press.

Wolz, A. and Pham, B.D. 2010. “The Transformation of Agricultural Producer Cooperatives: The Case of Vietnam”. Journal of Rural Cooperation, 38(2): 117-133.

Wurfel, D. 1993. “Doi Moi in Comparative Perspective”. In Reinventing Vietnamese socialism, Doi Moi in comparative perspective, edited by Turley, W.S. and Selden, M. Westview Press.

Yin, R.K. 1994. Case Study Research: Design and Method. 2nd edition, London: SAGE. 